\title{
Comparative Assessment of Students' Satisfaction with Hostel Accommodation in Selected Private Universities in Ogun State, Nigeria
}

\author{
Tajudeen Azeez \\ David Taiwo \\ Department of Urban and Regional Planning, \\ Crescent University, Abeokuta, Ogun State \\ Basirat Mogaji-Allison \\ Department of Estate Management, \\ Crescent University, Abeokuta, Ogun State \\ Azeez Bello \\ Department of Urban and Regional Planning, \\ Crescent University, Abeokuta, Ogun State
}

\section{Abstract}

The study assessed students' satisfaction with hostel accommodation in selected private universities in Ogun State, Nigeria. This was done by comparing the level of housing satisfaction of students residing in selected private universities' hostels. The study utilized structured questionnaires to obtain primary data from students and university authorities in the two selected private universities in the study area. There were twenty two (22) hostels in the study area (15 hostels in Crescent University, Abeokuta and 7 hostels in Bells University of Technology, Ota). From these hostels, Five (5) hostels from Crescent University and three (3) hostels from Bells University of Technology was randomly selected. There were three hundred and eight (308) rooms in the eight (8) hostels selected. Simple random sampling was used to select thirty five percent (35\%) of the rooms in the study area. Thus, the sample size was one hundred and eight rooms (108) (65 from Crescent University and 43 from Bells University). Data obtained were analyzed through the use of descriptive statistics such as frequency tabulation to assess the general levels of students' housing satisfaction, and also the use of Relative Satisfaction Index (RSI) to determine the degree of students' satisfaction with each of the housing components identified for the study. The results revealed that students in Bells University of Technology were more satisfied with their hostel accommodation compared to students of 
Crescent University (RSI $=4.22$ and 3.65 respectively for Bells University of Technology, Ota and Crescent University, Abeokuta). The study indicated that the standard of housing components can significantly influence students' satisfaction with their hostel accommodation. It is therefore pertinent that the university authorities should consider the provision of adequate and quality infrastructure when planning and designing students' housing.

Keywords: Housing, hostel accommodation, students' housing satisfaction, private universities, Abeokuta, Ota, Ogun state

\section{Introduction}

Housing has been viewed by Jiboye (2010) as any type of permanent shelter for man, which gives him an identity. Housing in all its ramifications is more than mere shelter. It embraces all the social services and utility that goes to make a community or neighbourhood a liveable environment (Federal Government of Nigeria (FGN), 1991; Jiboye, 2010). Good housing and decent accommodation play a significant role in healthy living and lead to improved productivity. This is particularly true for a special category of individuals-students, especially those in tertiary institutions, who require good accommodation in a serene environment for proper assimilation of what they have been taught.

Students' hostel accommodation has been one of the major challenges in Nigeria tertiary institutions due to explosion in students' population (Akpan, 1998; Offiong, 2002). Likewise, residing in students' housing faraway from family for a long period of time is an enduring experience for young students (Khozaei, Ayub and Hassan; 2010). The majority of the students admitted are below the age of eighteen and a substantial proportion never left home or had previous hostel experience (Amole, 1997).

Students' housing form part of the facilities that students take into consideration before making a choice of the school they intend to attend among other considerations (Price et al., 2003). This therefore makes it imperative for schools to give students housing a top priority while enhancing the reputation of the school among other contemporaries. The students' housing is said to include facilities such as bedrooms which can serve the dual purpose of sleeping and study, toilets and bathrooms, kitchen, laundry, recreational areas and access to internet services as this further enhance the study-learning experience. Abramson (2009) on his part, asserted that the student housing can be further made exciting by providing further facilities such as car park, mini markets, bookshops, cafeterias and ATM machines within the precinct of the students' housing. 
Students' housing has not received the desired attention both from the government and the management of the institutions in Nigeria. Ubong (2007) observed that hostel accommodation has not received adequate attention although it is an important component of pupil personnel management, inadequate maintenance of the services and infrastructure of hostel accommodation is very common. There have been reported cases of students taking ill in the hostels as a result of poor sanitary conditions. It is crucial to note that student hostel must not only be adequately provided for in relation to the student population of a university, but it must also be able to satisfy their needs if the best is to be appropriated from them.

Conceptually, housing satisfaction according to Djebarni and AlAbed (2000) refers to the degree of contentment experienced by an individual or family with regard to the current housing situation. It is an index for determining the level of contentment with housing. Satisfying users of any facility (including hostel facility) should be one of the main objectives of providing such facility in the first instance. Singh (2006) believes that user satisfaction has a positive effect on an organisation's profitability, educational institution inclusive. Some authors further state that it is not enough to merely satisfy users but importantly, ensure users are extremely satisfied (Sivadas and Baker-Prewitt, 2000; Bowen and Chen, 2001).

Numerous studies (Amole 2009, Lotfi and Solaimani 2009, Jiboye 2010) have examined various aspects of satisfaction, including residential satisfaction, customer satisfaction, job satisfaction and environmental satisfaction. However, there is paucity of studies on residential satisfaction among students most especially in private universities.

Hence, it is pertinent that study is conducted to ascertain students' satisfaction with hostel facilities put in place because when students are satisfied with the facilities provided in their residence halls, it will lead to enhancement in the academic excellence of the students; students overall enrollment and reduction in complaints being filed against the management among others. It is on this note that this study attempts a comparative assessment of students' satisfaction with their hostel accommodation in private universities by positing the case of Crescent University, Abeokuta and Bells University of Technology, Ota in Ogun state, Nigeria.

\section{Literature Review and Theoretical Framework}

Housing has been universally acknowledged as one of the most essential necessities of human life and it is a major economic asset in every nation (Jiboye, 2010). Adequate housing provides the foundation for stable communities and social inclusion (Oladapo, 2006). People's right to shelter is thus a basic one and the provision of decent housing to all requiring them 
should be the hallmark of every civilized society and one of the criteria for gauging development.

The conception of student housing draws upon the model of the conventional family housing. For Sixsmith (1986), home is not a single place for each person; rather, a number of places can be filling this role simultaneously. Klis van der and Karsten (2008) argue that home can be a dual-residence situation in which one dwelling is near the workplace and the other is the family residence (hometown). This concept as referenced by Sixsmith (1986) and Klis van der and Karsten (2008) are comparable to commuter residence. A student, for example, has both a university house close to college and a home in his or her hometown. Students demand and acquire a second residence (i.e., university housing), where they stay during workdays and the second residence is temporary in nature. Moore (2000) and Barnes et al. (2009) suggest that people attach a variety of connotation to their understanding of house. Thus, Sitar and Krajnc (2008) claim that old houses need to be renovated for living comfort confirmation, compromise innovative technologies and fulfilled inhabitants needs. The understandings among students of their student housing are similarly diverse.

\section{Halls of Residence (On Campus)}

Halls of residence are accommodation provided by the university, though at a cost to the student. These halls may be mixed sex or single sex, catered or self-catering, with single rooms or shared rooms and with ensuite bathrooms or shared bathrooms. The cost of these rooms will vary according to these variables and the university you attend, and there may be further rules such as visiting hours, quiet hours, alcohol and guest policies and opening hours out of term. This type of accommodation is usually in short supply and also it is an added advantage to the students who are from low income background because of its low cost, availability of social amenities and nearness to the lecture rooms.

\section{Concept of Housing Satisfaction}

Satisfaction in housing means the sentiments of satisfaction and happiness to the housing place which creates these feelings (Abramson, 2010). Housing is often viewed as an entity involving a large number of units displaying aspects such as physical quality, location, standard of services offered by the government and private owners as well as neighbourhood characteristics (Curley, 2003). The physical entity of housing ties down a person or family to personal services and relationships. A housing that fulfills one's daily needs provide a high satisfaction rate to occupants. 
Satisfaction towards the living conditions means no complaints are made since the housing units fulfill the needs and aspirations of the residents. Satisfaction towards the housing environment reflects residents' reaction towards their living environment. In general, housing has been accepted as a main component towards a quality life.

The concept of housing satisfaction is multi-layered. Elsinga and Hoeksta (2005) and Hassanain (2008) display similar views on the concept of housing satisfaction based on their observation on past studies. In their opinion, the concept of housing satisfaction has been used for four major objectives. It is the key to predict an individual's perception on the overall quality of life. It is also an indicator of individual mobility which later changes the demand on housing and influences surrounding area change; it is used as an ad hoc measurement of private sector development success as an evaluation tool to measure resident's acceptance of prevailing shortcomings for existing surrounding area development. Finally, housing satisfaction acts as a variable in determining the relationship between the resident's background and his attitude towards mobility.

There are factors that are associated with housing satisfaction. These factors can be broadly categorized as physical, social and management factors. Physical factors are those related to the physical characteristics of a dwelling and its surrounding environment. Regarding the physical factors, empirical studies have shown that housing satisfaction is associated with an improvement of security control (Mohit, Ibrahim and Rashid 2010); dwelling design and privacy (Day, 2000); unit size and length of stay (Fang, 2006); property value, housing adequacy and available housing space, adaptability and flexibility of spaces (Berkoz et al., 2009); and satisfaction with the facilities of surrounding environment (Patricia and Yusof, 2013). All of these factors emphasize the importance of the physical attributes of the constructed environment on residents' satisfaction.

Social factors concern the personal characteristics of the people who reside in these dwellings as well as their feelings and perceptions of the environment. Studies have shown that housing satisfaction is associated with the personality characteristics of the residents (Bruin and Cook, 1997), perceived quality and physical comfort (Khozaei et al., 2007), residents' relationship with management staff (James et al., 2009), home ownership (Elsinga and Hoekstra, 2005) and aggregate income (Frank and Enkawa, 2008).

A lot of scholars have more specifically focused on student housing satisfaction. Najib, Yusuf and Abidin (2011) studied student residential satisfaction in research universities. The study identified some significant predictors of student housing satisfaction, such as "cleanliness, safety, hall program and activities, and opportunities to provide input into decision 
making in the hall". Similarly, Ubong (2007) study concluded that "high quality facilities, positive roommate relationships, strong floor communities and quiet study environments are the most important predictors of students' satisfaction with their hall". Studies show that giving freedom to students to choose their own roommate increases their level of housing satisfaction (Stern et al., 2007).

Amole (2009) reported the results of a study of residential satisfaction in students' housing in Nigeria. The study examined how satisfied students were and the factors which predicted residential satisfaction. Specifically, it examined whether the morphological configurations of the halls of residence would predict residential satisfaction. Data were obtained from questionnaires distributed to a sample of 1124 respondents from all the halls of residences in four residential universities in Southwestern Nigeria. More than half (53\%) of the respondents were dissatisfied with their residences and the variables which explained satisfaction were the social qualities of the residences, especially, the social densities; the kitchenette, bathroom and storage facilities and some demographic characteristics of the students. The morphological configuration of the halls of residence was also found to be a predictor of satisfaction and the characteristics which appeared most significant were the plan form and the length of the corridor.

Najib, Yusuf and Abidin (2011) investigated the level of student satisfaction with campus student housing facilities (SHF) at Malaysian Research Universities (RUs) and the relationship between satisfaction and loyalty behaviour. The student residential satisfaction (SRS) framework was proposed to investigate residential satisfaction from the students' viewpoint. In general, students are satisfied with the provided SHF with the SRS index of 2.96 or 74 per cent satisfaction level and there is a significant relationship between overall satisfaction and loyalty behaviour. The results also confirmed that the proposed model was an adequate instrument to measure SRS.

Foubert et al. (1998) in the United State, Kaya and Erkip (2001) and Khozaei et al. (2010) in Malaysia also evaluate student housing satisfaction, focusing on perceptions of room size and crowding in Turkey. In Saudi Arabia, Hassanain (2008) studies the degree of satisfaction in terms of both technical performance (i.e. thermal comfort and functional performance (i.e. room layout and furniture quality) in sustainable student housing facilities.

Most previous studies however do not address a broad spectrum of satisfaction with student housing and thus, they are unable to provide guidance for student housing managers and university administrators. Assessing the level of students' satisfaction would therefore require evaluating a particular hostel accommodation located within a particular 
environment that is managed under a certain type of institutional management (Onibokun 1974; Oladapo 2006).

Nevertheless, studies of human perception and behaviour have shown that the interaction and interdependence of the components of a subsystem act as a stimulus to an individual in forming a cognitive image or mental picture of oneself and each of the other interacting components. Such an image becomes the basis of one's attitude and feelings towards each of the components of the system, and the totality of these feelings is the basis on which one's relative satisfaction with each subsystem depends.

The use of this information on housing has been negligible in most third world countries such as Nigeria. Therefore, this work is designed to identify various concepts contributing to satisfactory student housing. This would provide all stakeholders in student housing development with valuable data on which an ideal student-dwellingenvironment-management interaction could be based.

\section{Study Area}

Ogun State was carved out of the old Western State by the military administration of General Murtala Muhammed and General Olusegun Obasanjo in February 1976. The new state was made up of the former Abeokuta and Ijebu provinces of the former Western State, which itself came into being when it was carved out of former Western Region in 1967.

Ogun State is otherwise known as the Gateway State and has 20 Local Government. The State is entirely in the tropics. Located in the Southwest Zone of Nigeria with a total land area of 16,409.26 square kilometres, it is bounded on the West by the Benin Republic, on the South by Lagos State and the Atlantic Ocean, on the East by Ondo State, and on the North by Oyo and Osun States. It is situated between Latitude $6.2^{\circ} \mathrm{N}$ and $7.8^{\circ} \mathrm{N}$ and Longitude $3.0^{\circ} \mathrm{E}$ and $5.0^{\circ} \mathrm{E}$. 


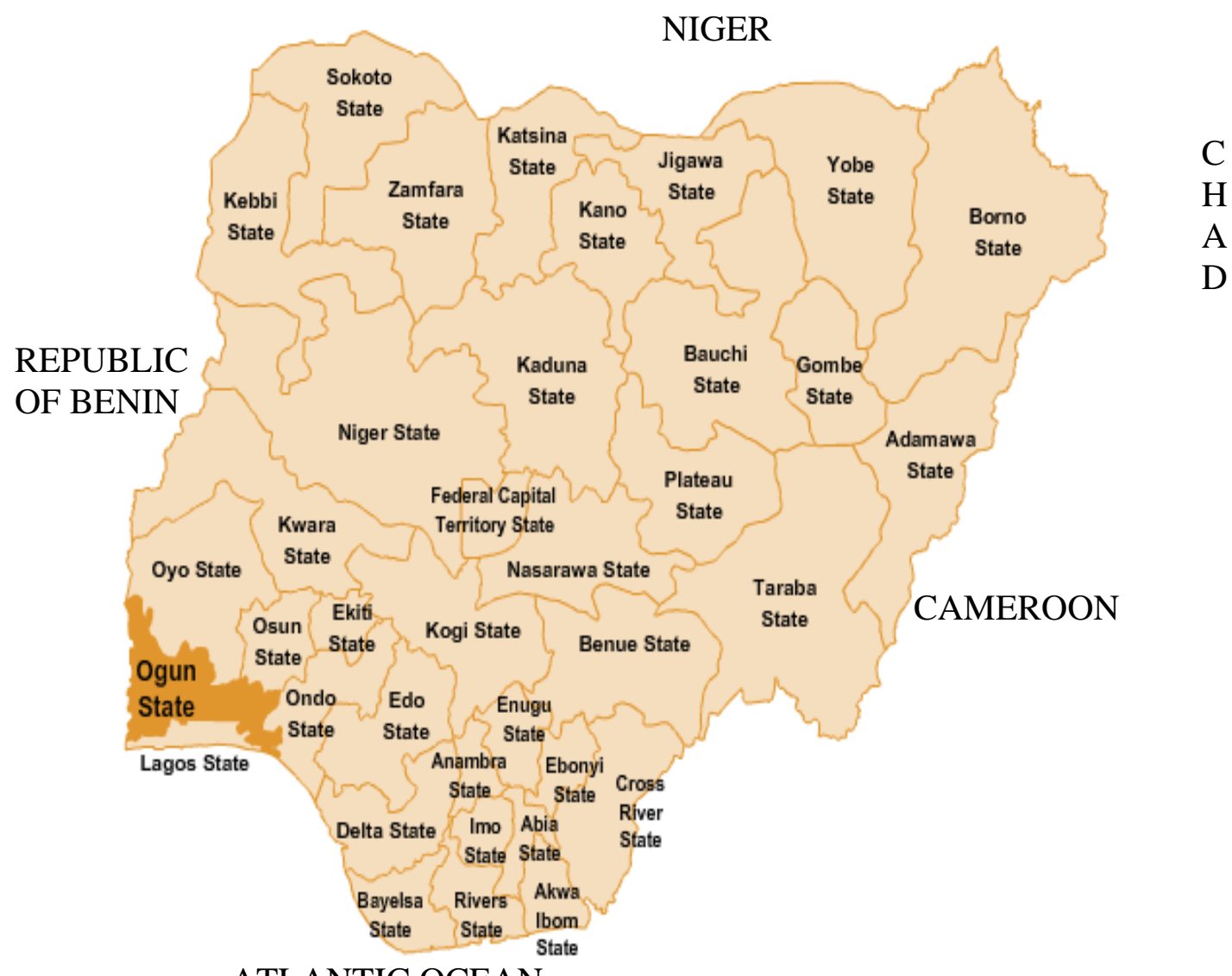

ATLANTIC OCEAN

Scale: 1:6,000,000

Figure 1: Map of Nigeria showing Ogun State

Source: Wikipedia, 2012

\section{Crescent University, Abeokuta}

Crescent university, Abeokuta was established as a private university by the Islamic Mission for Africa (IMA) in consonance with her doctrine and vision. The operating license from the Federal Government of Nigeria was obtained from the National University Commission in 2005. The mission of the University is to ensure the delivery of University education in ways that recognize personal discipline and integrity and promote positive societal values. The University is out to assist in closing the widening gap between attainable potential student population and limited space in Nigerian educational system. Thus, the University hopes to produce the kind of graduates that will fit into current economic agenda of the nation.

Crescent university is primarily residential with halls of residence for both male and female students. The names of the halls of residence are: Dantata Hall, Prof. Hassan K. A. Hall, Saudi Hall, Dangote Hall, 
Mohammed Mahruf Hall, Tijjani Folawiyo Hall, Zakariya Hall, Lateef Adegbete Hall, Yola Hall, Ushape Hall, New Hostel, Iqra Hall, Hameeda Hall, Amota Hall, and Gbadela Hall. The analysis of halls of residence in Crescent University is presented in Table 1.

Table 1: Names and capacity of hostels in Crescent University, Abeokuta

\begin{tabular}{|c|c|c|c|c|c|}
\hline S/N & $\begin{array}{c}\text { Name of the } \\
\text { hostels }\end{array}$ & $\begin{array}{c}\text { Type of } \\
\text { building }\end{array}$ & $\begin{array}{c}\text { Number of } \\
\text { rooms }\end{array}$ & $\begin{array}{c}\text { Students per } \\
\text { room }\end{array}$ & Total \\
\hline 1 & Dantata & Storey & 36 & 4 & 144 \\
\hline 2 & Prof. Hassan K.A & Storey & 40 & 4 & 160 \\
\hline 3 & Saudi hall & Storey & 40 & 4 & 160 \\
\hline 4 & Dangote hall & Storey & 36 & 4 & 144 \\
\hline 5 & $\begin{array}{c}\text { Mohammed } \\
\text { Mahruf }\end{array}$ & Bungalow & 10 & 4 & 40 \\
\hline 6 & Tijjani folawila & Bungalow & 10 & 4 & 40 \\
\hline 7 & Zakiriya & Bungalow & 10 & 4 & 40 \\
\hline 8 & Latef Adebete & bungalow & 10 & 4 & 40 \\
\hline 9 & Yola & Storey & 10 & 4 & 40 \\
\hline 10 & Ushape & Bungalow & 10 & 4 & 40 \\
\hline 11 & New hostel & Storey & 60 & 2 & 120 \\
\hline 12 & Iqra & Bungalow & 10 & 4 & 40 \\
\hline 13 & Hameeda & Bungalow & 10 & 4 & 40 \\
\hline 14 & Amota & Bungalow & 10 & 4 & 40 \\
\hline 15 & Gbadela & Bungalow & 10 & A10,11 are 2 & 36 \\
\hline & Total & & 312 & & 1,124 \\
\hline
\end{tabular}

Source: Authors’ field work, 2016

\section{Bells University of Technology, Ota, Ogun state, Nigeria}

Bells University of Technology, Ota, Ogun state, Nigeria is the First Private University of Technology in Nigeria. It was granted operational license on 9th June, 2005 and commenced operation on 1st July, of the same year. The idea of Bells University of Technology was conceived following the desire of the Bells Educational Foundation to establish a unique University where the good foundation given to products of its Secondary School and other Secondary Schools could be built upon. In order to realize its dream, the Bells Educational Foundation obtained an application form for the establishment of a Private University from the National Universities Commission (NUC) on 10th January, 2002 and submitted the application forms on 10th November, 2004. A Planning and Implementation Committee was subsequently constituted, made up of former Vice-Chancellors of reputable Universities, top Academic staff and seasoned University Planners. under the table Chairmanship of Prof. Tekena N. Tamuno, OFR, CON, a former Vice-Chancellor of the University of Ibadan.

On 9th June, 2005, the Bells Educational Foundation was issued with a license for the operation of a private University; Bells University of Technology. In view of the desire to commence both administrative and 
academic activities at the University within the Academic Session, NUC approved that the Ota site situated along Bells Drive, off Ota-Idiroko road, which had physical structures and some facilities in place, would serve as the take-off site of the University.

Bells University of Technology is basically residential with hostel accommodation for both male and female students. The names of the hostels are as follows: New silver hostel (male hostel), Silver Hall (Male), Male Hall, Bronze Hall, Female Silver Hall, Female Hall1, and Female Hall 2 (See Table 2).

\begin{tabular}{|c|c|c|c|c|c|}
\multicolumn{1}{c|}{ Table 2: Names and capacity of hostels in Bells University of Technology, Ota } \\
\hline S/N & $\begin{array}{c}\text { Name of the } \\
\text { hostels }\end{array}$ & $\begin{array}{c}\text { Type of } \\
\text { building }\end{array}$ & $\begin{array}{c}\text { Number of } \\
\text { rooms }\end{array}$ & $\begin{array}{c}\text { Students per } \\
\text { room }\end{array}$ & Total \\
\hline 1 & New silver & Storey & 78 & 6 & 468 \\
\hline 2 & Silver & Storey & 78 & 6 & 468 \\
\hline 3 & Male hall & Bungalow & 23 & 4 & 92 \\
\hline 4 & Broanze & Storey & 78 & 6 & 468 \\
\hline 5 & Female silver & Storey & 78 & 6 & 468 \\
\hline 6 & Female hall 1 & Bungalow & 23 & 4 & 92 \\
\hline 7 & Female hall 2 & Bungalow & 23 & 4 & 92 \\
\hline & Total & & 381 & & 2,148 \\
\hline
\end{tabular}

Source: Authors' field work, 2016

\section{Materials and Methods}

The information on which this study is based is majorly from primary sources. Primary data was collected through the administration of questionnaire to students in the two selected universities. There were fifteen (15) hostels in Crescent University, Abeokuta and seven (7) in Bells University of Technology, Ota. These hostels were for both male and female students of the Universities.

The sample frame was 35\% of the hostels in the two selected universities in the study area. This amounted to five (5) hostels in Crescent University and three (3) hostels in Bells University of Technology, making a total of eight (8) hostels in the two (2) selected universities. The five selected hostels in Crescent University; Abeokuta has one hundred and eighty two rooms (182) while the three (3) selected hostels in Bells University of Technology have one hundred and twenty four (124) rooms. Thus, the eight (8) selected hostels in the two universities have a total of three hundred and eight (308) rooms.

Simple random sampling was used to select thirty five percent (35\%) of the selected rooms in the two universities. Therefore, a total of one hundred and eight (108) rooms were selected for the survey. Since the unit of investigation was the students, a student was selected in each of the rooms for questionnaire administration. 
Data collected was analyzed using descriptive statistics and relative satisfaction index (RSI). The relative students' satisfaction index (RSI) was obtained by using 5-point Likert Scales of 'Very satisfied', 'Satisfied', 'Indifferent/just satisfied', 'Dissatisfied' and 'Very dissatisfied'. The scale used the following responses: Each response was coded accordingly: Very Dissatisfied $=1$, Dissatisfied $=2$, Indifferent/Just satisfied $=3$, Satisfied $=4$ and Very Satisfied $=5$. Each coded response was multiplied by number of respondents, which gave the Weighted Value (WV). The Summation of the Weighted Values ( $\sum \mathrm{WV}$ ) was divided by number of respondents $(\mathrm{n})$ to arrive at each component Mean Weighted Value (MWV). The Mean of Mean Weighted Value (MWV) was then obtained by dividing Summation of Mean Weighted Value ( $\sum \mathrm{MWV}$ ) by total number of housing condition variables (y) surveyed in the study. This gave the overall satisfaction. Thus, MWV = $\sum \mathrm{WV} / \mathrm{n}$, where $\mathrm{n}=$ population of respondents. Overall satisfaction $=$ Mean of $\mathrm{MWV}=\sum \mathrm{MWV} / \mathrm{y}, \mathrm{y}=$ total number of variables.

\section{Data Analysis and Discussion}

This section deals with the evaluation of the students' level of satisfaction with their hostel accommodation in Crescent University, Abeokuta and Bells University of Technology, Ota. As depicted in Table 3, students in Crescent University, Abeokuta, were satisfied with the size of their rooms (RSI=3.52); verandah/sit-out (3.90); hostel waste disposal (4.22); hostel security (3.80). Similarly, they also claimed that they were satisfied with water supply (RSI=4.09); power supply (4.28); hostel environment (3.94); proximity of hostel to lecture theatres (4.20); room privacy (4.03); room ventilation (4.17) and hostel maintenance (3.92). In addition, the students were just satisfied with condition of their toilets (RSI=3.18); bathroom (2.98), laundry room (3.32); number of occupants (3.45); common room (3.26) drainage system (3.40) and hostel rules (3.17). Besides, the students' claimed that they were not satisfied with recreational facilities in the hostels (RSI=2.68). However, the overall satisfaction index of the students with their hostel accommodation was 3.65 (fairly satisfied).

Meanwhile, in Bells University of Technology, Ota, the students claimed that they were satisfied with the following hostel infrastructure: condition of hostel toilets (RSI=4.12); bathroom (4.12); laundry (4.28); room size (4.19); verandah/sit-out (4.44); drainage (4.42); waste disposal (4.07); hostel security (3.95); water supply (4.14); power supply (4.00) hostel environment (4.42) recreational facilities (3.95); room privacy (4.44); hostel rules (4.19) and hostel maintenance (4.26). The students' indicated that they were very satisfied with hostel common room (RSI=4.58); proximity of hostel to lecture theatres (RSI=4.63) and room ventilation (4.63). However, they expressed their indifference with the number of room occupants (3.28). 
The overall satisfaction index of the students' with the hostel was 4.22 (satisfied).

On the corollary, comparing the students' satisfaction with their hostel accommodation in the study area, it can be perceived that students' of Bells University of Technology, Ota were more satisfied with their hostels than students in Crescent University, Abeokuta.

Table 3: Students' satisfaction with hostel accommodation in the study area

\begin{tabular}{|c|c|c|c|c|c|c|c|c|}
\hline \multirow{3}{*}{$\mathrm{S} / \mathrm{N}$} & \multirow{3}{*}{ Facilities } & \multicolumn{5}{|c|}{ Rating and Weighted Values } & \multirow{3}{*}{ SWV } & \multirow{3}{*}{ RSI } \\
\hline & & 5 & 4 & 3 & 2 & 1 & & \\
\hline & & VS & $\mathrm{S}$ & FS & $\mathrm{D}$ & VDS & & \\
\hline \multicolumn{9}{|c|}{ Crescent University } \\
\hline 1. & Condition of toilets & 13 & 17 & 14 & 11 & 10 & 207 & 3.18 \\
\hline 2. & Condition of bathrooms & 13 & 18 & 16 & 11 & 7 & 194 & 2.98 \\
\hline 3. & Laundry & 5 & 21 & 29 & 10 & 0 & 216 & 3.32 \\
\hline 4 & Room size & 6 & 31 & 19 & 9 & 0 & 229 & 3.52 \\
\hline 5. & Number of occupants & 6 & 29 & 18 & 12 & 0 & 224 & 3.45 \\
\hline 6. & Verandah/sit-out & 27 & 13 & 17 & 8 & 0 & 254 & 3.90 \\
\hline 7. & Common room & 19 & 12 & 9 & 17 & 8 & 212 & 3.26 \\
\hline 8. & Drainage system & 10 & 17 & 29 & 7 & 2 & 221 & 3.40 \\
\hline 9. & Hostel waste disposal & 21 & 37 & 7 & 0 & 0 & 274 & 4.22 \\
\hline 10. & Hostel security & 11 & 30 & 24 & 0 & 0 & 247 & 3.80 \\
\hline 11. & Water supply & 25 & 21 & 19 & 0 & 0 & 266 & 4.09 \\
\hline 12. & Power supply & 26 & 31 & 8 & 0 & 0 & 278 & 4.28 \\
\hline 13. & $\begin{array}{l}\text { Clean and healthy } \\
\text { environment }\end{array}$ & 13 & 39 & 9 & 4 & 0 & 256 & 3.94 \\
\hline 14. & $\begin{array}{c}\text { Proximity of hostel to lecture } \\
\text { theatre }\end{array}$ & 22 & 34 & 9 & 0 & 0 & 273 & 4.20 \\
\hline 15. & Recreational facilities & 5 & 11 & 19 & 18 & 12 & 174 & 2.68 \\
\hline 16. & Room privacy & 17 & 33 & 15 & 0 & 0 & 262 & 4.03 \\
\hline 17. & Room ventilation & 18 & 40 & 7 & 0 & 0 & 271 & 4.17 \\
\hline 18. & Hostel rules & 23 & 19 & 16 & 7 & 0 & 206 & 3.17 \\
\hline \multirow[t]{4}{*}{19.} & Hostel maintenance & 12 & 36 & 17 & 0 & 0 & 255 & 3 \\
\hline & & & & & & & & .92 \\
\hline & Total & & & & & & & \\
\hline & \multicolumn{8}{|c|}{ Mean of $\sum M W V=69.51 / 19=3.66$} \\
\hline
\end{tabular}

Bells University of

Technology

1. Condition of toilets

2. Condition of bathrooms

Laundry

Room size

Number of occupants

Verandah/sit-out

Common room

Drainage system

Hostel waste disposal

Hostel security

Water supply

Power supply

Clean and healthy

environment

$\begin{array}{ccccccc}13 & 22 & 8 & 0 & 0 & 177 & 4.12 \\ 13 & 22 & 8 & 0 & 0 & 177 & 4.12 \\ 17 & 21 & 5 & 0 & 0 & 184 & 4.28 \\ 19 & 13 & 11 & 0 & 0 & 180 & 4.19 \\ 5 & 21 & 17 & 0 & 0 & 160 & 3.27 \\ 23 & 16 & 4 & 0 & 0 & 191 & 4.44 \\ 25 & 18 & 0 & 0 & 0 & 197 & 4.58 \\ 18 & 25 & 0 & 0 & 0 & 190 & 4.42 \\ 8 & 30 & 5 & 0 & 0 & 175 & 4.07 \\ 11 & 21 & 9 & 2 & 0 & 170 & 3.95 \\ 15 & 19 & 9 & 0 & 0 & 178 & 4.14 \\ 16 & 23 & 4 & 0 & 0 & 172 & 4.00 \\ 25 & 11 & 7 & 0 & 0 & 190 & 4.42\end{array}$




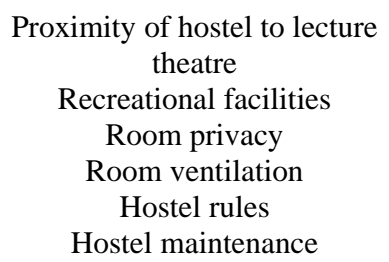

\begin{tabular}{|c|c|}
\hline 27 & 16 \\
\hline 7 & 27 \\
\hline 24 & 14 \\
\hline 27 & 16 \\
\hline 13 & 25 \\
\hline 17 & 20 \\
\hline
\end{tabular}

Total

\section{Conclusion}

The study has established that there is variation in the level of students' satisfaction with their hostel accommodation in the selected private universities in the study area. From this study, it is arguable that living satisfaction is a multiple concept of the indices of satisfaction which students perceive with living condition, social activities, facilities and services, neighbourhood physical surroundings, living cost and students' preference. Though, satisfaction is strictly based on individual perspective, the result shows that in general, students in Bells University were more satisfied with their hostel accommodation compared to students in Crescent University, Abeokuta.

The study concluded that available utilities and facilities such as verandah/sit-out, waste disposal, wall, doors, portable, drainage, condition of roofs and condition of windows were in good condition. Moreover, despite majority of the students believing their rooms are spacious, findings has revealed that the rooms are not too okay for the students especially in Crescent University. Therefore overcrowding is a problem experienced in some of the hostels. Furthermore, it was discovered that condition and distance to facilities, hostel power supply, water supply and waste disposal were some of the major factors influencing students' satisfaction with their hostels in study area.

In this regard, the study recommends the need for the university authorities to build more hostels for both male and female students to accommodate the growing population in a bid to check overcrowding in the hostels. Moreover, the school authorities should also provide basic facilities and ensure regular supply of water and electricity to the hostels. Also solid waste should be regularly evacuated to prevent environmental hazard in the hostels.

\section{Acknowledgement} collection.

I acknowledged the effort of Muhammed Tureta Shehu in data 


\section{References:}

1. Abramson, P. (2009). "Downsizing residence halls: space and costs", Living on Campus, 2009. College Housing Report, 12 (5), pp. 20-27.

2. Abramson, P. (2010). "Green and growing: sustainability and amenities are increasing in new residence hall projects", Living on Campus, 2010 College Housing Report, 13 (5). pp. 20-30.

3. Akpan, G. E. (1993). The Effect of Student Income Support on Academic Performance. The Nigerian Journal of Economic and Social Studies, 40(2), pp. 285-293.

4. Amole, D. (1997). "An Evaluation of Students Residential Facilities in Some Nigeria Universities”. Unpublished PhD Thesis. Department of Architecture, ObafemiAwolowo University, Ile Ife, Nigeria.

5. Amole, D. (2009). Residential Satisfaction in students' Housing. Journal of Environmental Psychology, vol. 29, p.76-85.

6. Berkoz, L., Turk, S.S.E. and Kellekci, O.M.L. (2009). "Environmental quality and user satisfaction in mass housing areas: the case of Istanbul", European Planning Studies, 17, pp. 161-74.

7. Bruin, M.J. and Cook, C.C. (1997). "Understanding constraints and residential satisfaction among low-income single-parent families", Environment and Behavior, Vol. 29, pp.532-53.

8. Curley, P. (2003). "Residence halls: making campus a home", American School \&University, 75 (12), pp. 245-256.

9. Day, L.L. (2000). Choosing a house: the relationship between dwelling type, perception of privacy and residential satisfaction, Journal of Planning Education and Research, Vol. 19, pp. 265-75.

10. Djebarni, R. \& Al-Abed, A. (2000). Satisfaction Level with Neighbourhoods in Low-income

11. Public Housing in Yemen, Property management, 18(4). 230-239

12. Elsinga, M. and Hoekstra, J. (2005). Homeownership and housing satisfaction. Journal of Housing and the Built Environment, Vol. 20, pp. 401-424.

13. Fang, Y. (2006)."Residential satisfaction, moving intention and moving behaviours: a study of redeveloped neighbourhoods in innercity Beijing", Housing Studies, Vol. 21, pp. 671-694.

14. Federal Government of Nigeria (FGN) (1991). National Housing Policy, Chebichev Ventures.

15. Fitri, H. A. H., Ilias, A., AbdRehman, R., \&AbdRazak, M. Z. (2008). Service Quality and

16. Student Satisfaction: A Case Study at Private Higher Education Institutions. International Business Research, 01(03), 163-175. 
17. Frank, B.R. and Enkawa, T. (2008). "Economic drivers of dwelling satisfaction", International Journal of Housing Markets and Analysis, Vol. 2, pp. 6-20.

18. Hassanain, M.A. (2008), "On the performance evaluation of sustainable student housing facilities", Journal of Facilities Management, 6 (3), pp. 212-225

19. Jiboye, A. D. (2010). The Correlates of Public Housing Satisfaction in Lagos, Nigeria, Journal

20. of Geography and Regional Planning, 3(2), pp. 017-028.

21. Khozaei, F., Ayub, N. \& Hassan, A. S. (2010). The Factors Predicting Student's Satisfaction with University Hostels, Case Study, Universiti Sains Malaysia, Journal of Asian Culture and History, 2 (2).

22. Klis van der, M. and L. Karsten, (2008). Commuting partners, dual residence and the meaning

23. of home. Journal of Environmental Psychology. Pp. 235-245.

24. Lotfi, S. \& Solaimani, K. (2009). An assessment of urban quality of life by using analytic hierarchy process approach (case study: comparative study of quality of life in the North of Iran). J. Soc. Sci., 5: 123-133.

25. Mohit, M.A., Ibrahim, M. and Rashid, Y.R. (2010), "Assessment of residential satisfaction in newly designed public low-cost housing in Kuala Lumpur", Malaysia. Habitat International, 34, pp. 18-27.

26. Najib, N.U.M. (2011), "Residential satisfaction of student housing facilities in Malaysian public universities", MSc thesis dissertation.

27. Nor AiniSalleh, Nor’AiniYusof, Abdul GhaniSalleh, \& NorainiJohari (2011). Tenant Satisfaction in Public Housing and its Relationship with Rent Arrears: MajlisBandaraya Ipoh, Perak, Malaysia.

28. Offiong, G. (2002). How to Reverse Decay in Tertiary Institutions. Guardian Newspaper, Daily, February 26th, 2002.

29. Oladapo, A. A. (2006). A Study of Tenant Maintenance Awareness, Responsibility and Satisfaction in Institutional Housing in Nigeria Int. J. Strategic Prop. Manage Vilnius Gediminas Technology, University, 10: 217-231.

30. Omole, F.K (2001). Basic Issues in Housing Development, Femo Bless Publications, Ondo.

31. Onibokun, A. G. (1974). Evaluating Consumers' Satisfaction with Housing: An Application of a System Approach, Journal of American Institute of Planners, 40(3): 189-200.

32. Patricia, T.S. and Yusof N.A. (2013). "Students' satisfaction with hostel facilities in Nigerian polytechnics: a case study of Kaduna polytechnic", Journal of Facilities Management, 11 (4), pp. 306-322 
33. Price, I., Matzdorf, F., Smith, L. and Agahi, H. (2003). "The impact of facilities on student choice of university", Journal of Facilities, 21(10), pp. 212-222.

34. Singh, H. (2006). The Importance of Customer Satisfaction in Relation to Customer Loyalty and Retention, pp. 1-7.

35. Sitar, M. and K. Krajnc, (2008). Sustainable housing renewal. American Journal of applied

36. sciences. Pp. 61-66.

37. Sivadass, E. and Baker-Prewitt, J. L. (2000). An Examination of the Relationship Between Service Quality, Customer Satisfaction, and Store Loyalty. International Journal of Retail \& Distribution Management, 28 (2), pp. 73-82.

38. Sixsmith, J., (1986). The meaning of home: An exploratory study of environmental experience.

39. J. Environ. Psychol. Pp. 281-298.

40. Ubong, B. (2007). Hostel Accommodation in Tertiary Educational Institutions in Nigeria: To $\mathrm{Be}$ or Not to $\mathrm{Be}$, available at: www.basseyubong.com/HOSTEL\%20ACCOMMODATION. 